\title{
1. Cultural insecurity in a world of violence, fear and risk Michel Wieviorka
}

\section{INTRODUCTION}

The aim of this chapter is to examine the relation between security and culture, focusing on the threats and risks which affect societies today. Before beginning, it is appropriate to indicate how, historically, the question of cultural security has gradually come to the fore within the humanities and social sciences. I shall start with the notion of culture.

\section{HOW HAS THE CONCEPT OF 'CULTURAL SECURITY’ COME TO THE FORE?}

\section{Culture under Tension}

There have been countless attempts at a conceptual definition of culture; as far back as 1952 Kroeber and Kluckhohn counted 163. If we take the current debates, which, like many others began in the nineteenth century, when the focus was on the definition of the links between culture and nation, it is clear that while approaches vary, they do so in the main along an axis between two polar opposites. This axis is not only conceptual; in fact, it conveys the diversity in the range of viewpoints which are expressed in political and intellectual life at the most general level, beyond the humanities and social sciences, and it can fairly easily be associated with what is said about migrants in any given society.

At one extreme, culture appears as an essence; it is bequeathed to individuals who receive it as a legacy; it is reproduced. Culture here is close to identity, another term which is also unclear in conception. In the most extreme cases, culture is naturalized and becomes a fact of nature which goes along with racist ideologies and even with many conceptions of ethnicity.

At the other extreme, on the contrary, culture is ongoing, a permanent mixture, an invention, which is produced and not reproduced, and it owes much more to encounters, 'métissage' or a mix of 'races', and processes of 
creolization. When this conception prevails within a dominant group in society, it refers to much more open perceptions of the alterity of foreigners, migrants or minorities, and a generally democratic and progressive conception of culture.

In the present-day world, participation in culture therefore involves tension between the register of innovation and creativity and that of tradition. In addition, difficult economic conditions, racism, rationales of exclusion and fear may also encourage individuals and groups to turn towards traditions, and even to reinvent them, rather than being open to inventiveness, mixing with others and perpetual movement.

Is this a question of identity, reproduction, traditions and essence versus métissage, production, invention and change? In any actual, historical experience, whatever the scale, there may be elements which belong to one extreme or to the other, or intermediary variants. The role of research is precisely to establish this. It is not a question of choosing one theory as opposed to another, or one type of conception of culture as opposed to another, but of accepting the idea of a considerable diversity of possibilities. These may range from one extreme to the other of this axis, and possibly combine within a population, a group or even within the experience of an individual. A person may for example valorize the culture of certain groups of migrants, seeing therein a source of dynamism for their own society, and be concerned, for racist reasons, by the presence of other migrants.

The terms of the debate on the concept of culture are not new and were, in many respects, constructed in the nineteenth century. To put it another way, culture has been central to many of the discussions in the social sciences since their origin. But this image of a culture in tension between two very different types of rationale is essential if we wish to examine the question of security in times of global risks and threats, whether it be a question of economic fears and difficulties induced by globalization, terrorism or themes associated with the environment and the climate. For some, 'cultural security' refers to the possibility of reproducing their culture; for others, to the possibility of producing new cultural forms; and for many, it is a somewhat unstable, or 'liquid' mixture of both, to use Zygmunt Bauman's (2017) term.

\section{The Cultural and the Social}

Can the concept of culture be conceived of independently, or with a large degree of autonomy? Should we not consider how it is bound to and how it conflicts with others, beginning with society? More precisely, at least since Tönnies (1887) opposed society and community - one could say, society 
and culture - a central question is constantly posed, namely the place of the social in relation to the cultural. Are the two registers completely separate? Can one analyse cultural identities, their production, their functioning and their transformations without taking into consideration social inequalities, labour relations, poverty or wealth, vulnerability, exclusion, and so on?

The age of industry is now long gone. There, the social took pride of place, with labour and relations of production, the main characteristic being the structural conflict opposing the working-class movement, therefore a social movement, to the masters of labour. We are now entering a new age in which culture is at the core of community life and where cultural and identity movements, including in religious forms, seem to have become priorities.

But perhaps one of the consequences of the present social difficulties is that culture and cultural identities are becoming modalities for a defence of the individual and groups in situations in which their social problems are not dealt with adequately in political terms. An answer is provided here by those who explain the rise of nationalisms and other identity-based movements in social and economic terms, by globalization for example. This implies the impossibility of seeing in cultural phenomena anything other than a reaction of fear, a withdrawal, a form of retreat and a demand for frontiers to protect the nation from external threats. An extreme variant of this position are those who, like Michaels (2006), consider that by putting forward cultural demands, or claims for recognition of an identity, the actors involved and the intellectuals or the leaders who support them and accompany them are merely doing so to avoid consideration of social issues, and in the last resort are acting in the interests of neoliberal globalization and financial capitalism.

But this type of response avoids a key dimension of the centrality which culture now assumes, namely, whether it be materially dominated by rationales of invention and innovation or by rationales of reproduction, culture is the subject of demands for rights. These rights are part of the broader range of human rights, with their own specificity. As Marshall (1963) explained in a well-known lecture at the end of World War Two, civil rights, then political rights, and finally social rights have gradually been achieved in Europe and in North America since the eighteenth century. Today, in addition, there are cultural rights and claims for their extension, as is clearly stated by the signatories to the Fribourg Declaration on Cultural Rights (7 May 2007). The issue of culture is no longer a substitute for, or an addition to, the social question. It is a vast sphere for action and demands. 


\section{Cultural Rights and their Security Component}

There is an innovation here which is well worth consideration. Amongst these claims and demands, some involve security. As we have known since Hobbes, in matters of the political and institutional history of democracies, security is usually the domain of authority and of the state. People need to be protected, a degree of order must be maintained; in the first instance, the question is political. People need to eat, to educate their children, to have access to housing, health care and employment, and anything which deprives them or threatens to deprive them of this can be experienced as a form of insecurity. The issue then becomes social, and amongst the major responses those provided by the social-democratic schemes implementing the welfare state have been the most satisfactory. But today the question is also cultural, for if there are effectively risks and threats, these often target the cultural being constituted by a nation, a region or a specific group. In these instances, the security which is sought is one of being able to live with dietary, clothing, linguistic, intellectual and moral traditions, but also of being able to innovate, to invent, not to be attacked or threatened in one's integrity. This also includes the possibility of establishing oneself as a subject of one's experience on both an individual and a collective level. Cultural security involves on one hand the defence of what exists, which merely seeks to be reproduced; on the other, it involves the right to change and therefore to give free rein to imagining the metamorphoses of an identity.

The question has become both urgent, but also complex. One of the reasons is that we no longer live in a Westphalian world, to use the words of the political scientists who are referring to the treaties signed under the Peace of Westphalia in 1648, organizing Europe on a basis of nation-states capable of maintaining what has been known as international relations. Security, classically, involves the state; today the state is challenged in thousands of ways from both within and without. This is true at national level when, for example, the nation-state has to respond to global, Islamic terrorism from both internal and external sources. The same applies when the nation-state is faced with migratory flows from foreign countries, but also with the difficulties associated with the integration of immigrants in the country. This is also true at the level of groups for whom the space may be more restricted than that of the nation-state, for example groups claiming to adhere to regional identities, such as Corsica, Catalonia, Scotland, and so on. This may also be the case for groups whose space extends beyond the framework of the nation-state, in particular in the form of diasporas.

The complexity is also due to the fact that both the culture of a group, or of a nation, and also the nature of the insecurity are phenomena which 
are both objective and subjective. Threats, for example, constantly arouse fears which may be disproportionate, even illusionary; but the opposite may also occur when threats are ignored or underestimated. Culture, as Benedict Anderson masterfully demonstrated in relation to the nation, in a book which is now a classic (Anderson 1983), and as Arjun Appadurai suggests in particular at global level for diasporas in another important book (Appadurai 1996), is increasingly the result of 'imagined communities' and not of real groups which actually know each other and meet. The community is no longer grounded, but has become delocalized. Cultural security is all the more difficult to ensure in view of the fact that it must take into consideration problems as they are experienced, either as social constructions or, on the contrary, as they are overlooked, which is also a social construction. At the same time, consideration has to be given to realities which have to be taken into account, understood and measured as objectively as possible - which is never easy.

\section{THE ACTUAL EXPERIENCE OF CULTURAL INSECURITY ${ }^{1}$}

To illustrate these remarks an analysis of actual instances, beginning with a recent example in France, may prove useful. I restrict this to the problems posed for this country by present-day terrorism, that is, radical Islamism and the related issues of immigration and Islam.

\section{The Relationship to Knowledge: Political Actors and Scholars}

After the killings in January 2015 in Paris, the French Prime Minister, Manuel Valls, stated that to understand the processes which led some people to commit such barbarous acts, we had to turn to the humanities and social sciences. One year later, on the occasion of the commemoration of these same killings, he delivered a stirring speech in front of the kosher hypermarket where four Jews were assassinated by an Islamist terrorist, during which he declared that we should not try to explain these acts, that terrorism had to be fought and war waged on Daesh. In the meantime, there had been another series of extremely deadly terrorist attacks in France on 13 November. There was also a turning point in security comparable to the one we witnessed in the United States after the 9/11 attacks. In particular, measures granting exceptional powers to the executive and depriving the judiciary of part of their prerogatives were instituted.

Thus, in barely one year, a political leader of outstanding importance was apparently capable of a radical change in opinion and of considering 
that, confronted with extreme violence and evil, in the last resort military and repressive action is called for, and that it was no longer time for analysis and consideration. This change is set within a context of a general shift to the right in politics in France, as in other countries of Europe, and marks an increasing trend to authoritarianism, at the expense of democracy.

This is not due to chance but is based on a political analysis: public opinion wants strict measures, it expects to be promised security in times of crisis and violence, it demands more police, more army, more controls of all types, it wants action, it wants information about enemies and not opponents, about war and not negotiations. Public opinion wants action and not words.

With this example, we can introduce an important and rather general observation: the values, principles and, more generally speaking, the arguments advanced as a basis for action against evil, wars and violence tend to be a function of the situations and emotions which they invoke, rather than of moral, philosophical or intellectual arguments which may endeavour to influence reason. Somewhere between knowledge, culture, philosophy, the humanities and social sciences and peace, we have politics, and this is not a totally autonomous sphere.

Unfortunately, politics is not constructed in the respect of values, listening to philosophers or examining the analysis of researchers in the humanities and social sciences. Politics is based on the demands of public opinion. These in turn are dominated by fear, dread, and at the same time by feelings which have nothing to do with violent events as such, or at least not directly. People do wish to feel safe, admittedly, when faced with the risk of violence, but politics rapidly associates these risks with the presence on national territory of foreigners, immigrants, people who are culturally different, with the idea that these people are irreconcilably different and that they will never adapt to the local culture. In the case of radical Islamic terrorism, these differences are not restricted to a few young radicals. In most European countries, and not only there, these are rapidly attributed to all Muslims, who are suspected of being more or less favourable to terrorism, of facilitating it, understanding it and, since these Muslims constitute the majority of immigrants, or of the children of immigrants, the populations of immigrant origin as a whole are the object of a racist and xenophobic rejection. Henceforth, a considerable proportion of the population amalgamates requests for police and military security to deal with terrorism, strictly speaking, and more ambiguous expectations in which there is a desire to protect the national cultural heritage from being undermined from within and without by Islam and the immigrants. This is why, throughout the world, the cultural insecurity of the citizens in a 
country, combined with various other fears and anxieties, in particular economic, is an encouragement for policies for the closure of countries. As a consequence, walls are built along the borders, detention camps are opened, barriers of all sorts attempt to close the country, and those who wish to cross these barriers illegally often pay with their lives for doing so. The Mediterranean has become a cemetery for many migrants; every year, several thousands who attempt to cross it are drowned, the victims of unscrupulous people traffickers and terrible conditions of navigation.

Let me immediately add two further remarks which are equally valid for experiences other than France. The first is that culture, philosophy, the positions of leading intellectuals or the humanities and social sciences are not necessarily on the side of peace. The American president George W. Bush, in his decision to make what was a catastrophic war on Iraq, was highly influenced by the thinking of the 'neo-cons' or neo-conservative philosophers; and the French President Nicolas Sarkozy decided to involve France in military intervention in Libya to overthrow Khadafy, once again without much thought and with disastrous consequences, after a series of conversations with Bernard-Henry Lévy, one of the 'new philosophers'.

A second observation is that one would have to be totally ignorant of the way in which politicians work if one were to believe that on the whole they listen to people who think, or to those who represent the world of culture and knowledge. Almost a century ago, in two well-known lectures on 'Politics as a Vocation', the eminent German sociologist, Max Weber (2004), had already explained very clearly that the ethics of political actors are not the same as those in the humanities and social sciences.

Politicians act in function of an ethics of responsibility; they are interested in the material effects of the actions they implement. The ethics of researchers are a matter of conviction, based on higher principles. It would be naïve to think that that those who personify values, culture, scientific knowledge or intellectual arguments can exert a systematic, strong and long-lasting influence on political decision makers. That could of course occur, but generally speaking, if there is an influence, it is less direct. For example, a political actor might take into consideration the success of a mode of thought and the impact which a leading intellectual exerts on society, possibly through the media or, today, the social networks, and embrace the ideas of a thinker or an outstanding figure personifying the values of a culture.

Political decision making, including in democracies, is indeed based on criteria other than those which can be provided by culture or philosophy, values or scientific values, even if decision making does take these into consideration, find therein a source of inspiration, or manipulate them. In 
particular, political leaders consistently appeal to culture, traditions and values to justify their actions, no matter how war-like. For example, we are constantly reminded of the Nation, its history, its greatest moments, its past exploits, its heroic virtues and its capacity for resistance in adversity. The state leader who does not pursue this path in times of great tension, crisis and risk of war or terrorism is well aware that he will be judged negatively as soon as events prove him wrong. One might say that the path to peace is dangerous, and if political leaders agree to take it, many conditions have to be fulfilled.

\section{The Nation and its Borders}

The combination of economic concerns, fear of terrorism and the impression that these dangers threaten the life of the nation and its identity tend to strengthen nationalism and sovereignty. This can easily be observed in France, for example, where the fear of terrorism, but also of unemployment, vulnerability, exclusion and marginalization, feed into the idea that the country is being subjected to a process of cultural destruction as a result of the absence of borders. The Front National, whose candidate obtained one-third of the votes in the 2017 presidential election, has promised to reintroduce border controls if elected, to prevent migrants from entering clandestinely. This party also pursues a resolutely hostile policy towards Islam. Donald Trump has declared that the United States of America will be great, if it asserts itself. He bluntly states, 'America First'; and is not afraid to build walls, like the one planned the length of the frontier with Mexico. The United Kingdom has chosen Brexit, for several reasons including economic ones, but the campaign which paved the way for the 'yes' vote in the referendum included numerous appeals to British identity.

These findings suggest that political discourse does not simply promise cultural security alone, but as an integral part of social and economic measures. This security, in times of terrorist threats, includes support for total closure of French society, political and military repression, and the cultural homogeneity of the nation; security forms a whole. But it has to be recognized that in certain cases, the appeals for security have little connection with the calls for the closure of French society and the homogeneity of the nation; similarly, references to national identity may be made by open-minded citizens or intellectuals, concerned with promoting innovation and creativity and the free movement of people and goods, including cultural property. 


\section{Other Identities}

In times of terrorism, cultural security is a concept which also applies to groups within a nation-state, and which may have resources elsewhere, either in a diaspora or in a state. In France, the Jewish and the Muslim populations deserve further consideration in this respect (Khosrokhavar and Wieviorka 2017). I will therefore take France as an example to illustrate this point.

Since World War Two, the history of the Jews in France has been subject to considerable change. At the outset, in the 1960s, they conformed to the French republican model and were referred to as 'Israelites', a word which has now disappeared from everyday usage. They were French citizens, like the others, in the public sphere; their specific identity was private and unobtrusive. Then, for a number of reasons, their culture was transformed. During decolonization, a Jewish population arrived from North Africa, anti-Semitism declined and was now condemned by the Catholic Church; the state of Israel - reminiscent of David confronting Goliath (the Arab states) - enjoyed a very positive image. At this point, a process which one might describe as a form of ethnicization of the Jewish population in France became perceptible. This consisted in them being visible and active in the public sphere, thus adopting an increasingly communitarian and therefore cultural form of behaviour.

But, as from the end of the 1970s, this evolution came to an end and another phase began during which the Jews in France felt increasingly insecure. Anti-Semitism reappeared in the form of negationism, in particular within the Muslim populations and amongst extreme-right groups. Above all, in the 2000s, this anti-Semitism became deadly and Islamic. The incidents which occurred included the killing of three Jewish children and a teacher in Toulouse in 2012, the assassination of clients in the Hypercacher supermarket in November 2015, and various other less spectacular crimes. The Jews in France felt threatened, including physically, but also and more importantly in their moral and cultural integrity. Some turned to the public authorities, requesting more stringent protective measures, particularly for places of worship and culture. Others turned to the former republican model and decided to be less visible, for example by not wearing the kippa in public. Others, as a last resort, left France, with many going to Israel. Why this country? Primarily because they think they will be able to live their lives there fully as Jews, including in the public sphere. For this group, cultural insecurity has thus led to various forms of behaviour, many of which originate in fear, but where we also find the desire to live in keeping with their traditions, without having to hide or to practise their religion covertly in the private sphere alone. 
For Muslims in France, the issue is very different. The majority are of immigrant origin; they are the descendants of the men who came on their own to work in France in unskilled jobs in the 1950s, 1960s and 1970s, and who then chose to remain here, get married and have children. As from the 1980s, they have been targets for racism and nationalism, first as Arabs and then increasingly as Muslims. There were also social and economic dimensions, but gradually the impression grew of a different culture becoming established in France, one which was unlike any other and could not be incorporated. The immigrants and their children have been accused both of 'taking the jobs of the French' and of developing an unacceptable form of communitarianism, imposing their culture visibly. With the 9/11 Islamist attacks, in particular in Spain (Madrid in 2004) and in the United Kingdom (London in July 2005), and above all in Paris in January and November 2015, and in Nice in July 2016, these same Muslims were caught up in ambivalent processes.

To begin with, there was a rise in the racism towards them. They were suspected of sympathizing to some extent with the murderers of the journalists at Charlie Hebdo. This is a satirical publication which had reproduced caricatures of the Prophet Mohamed and had therefore been guilty of blasphemy. They were also suspected of approving of the killing of the Jewish clients in the Hypercacher supermarket; a tangible anti-Semitism could be observed in this population. But the attacks in November 2015 and the carnage in Nice in July 2016 targeted no specific population, and there were several Muslims amongst the victims. From this point on, there was no basis for the tendency to condone terrorism of which some Muslims were suspected. It became possible for Muslim organizations to appear publicly alongside Christians in some demonstrations, and more generally for Muslims in France to be perceived as victims, and not as possible sympathizers with terrorism. This experience shows us that the impact of terrorism is never predictable and that one and the same group can, depending on the circumstances, be perceived in different ways in the representations made of them and in public opinion.

For a group such as the Muslims, cultural insecurity assumes the form of discrediting, discrimination (particularly in employment) and racism, but also of suspicion and even of paradoxical requirements. For example, they are often expected to be invisible, Muslims only in the private sphere, and at the same time to assume positions as Muslims in the public sphere and state that they condemn Islamic terrorism. Thus, the French example suggests that the question of cultural security varies in time and space, and from one group to another. 


\section{Cultural Security and Peace}

Cultural security should mean peace and not war, debates and negotiations and not civil war, institutionalization of conflicts and not violence and terrorism. This means that embedded in the culture of a society there exists a high degree of acceptance of the values of peace, discussion and negotiation, and a considerable capacity to resist tendencies to closure and violence.

Under what conditions will civil society demonstrate its capacity to understand and to desire peace and not war or violence? When many voices in a society call for peace, refusing violence, or demanding an end to it, when those who formulate these demands - religious leaders, intellectuals, politicians or heads of non-governmental organizations (NGOs), for example - succeed in making their voices heard, the likelihood of forcing the whole political system to go in this direction is obviously greater. These voices may take root in political cultures which range from neutrality, as in Switzerland, or systematically seek dialogue and peace, which is the case at international level for the Scandinavian countries and Canada. Therefore, I next examine these two points, the movement of society and the role of the experts, or intellectuals in the broad meaning of the term.

\section{The construction of the enemy}

When peace is threatened by the emergence of a threat of a war with a foreign enemy, or as a result of internal violence which could lead, for example, to a civil war, then martial speeches, appeals to authority, the defence of the nation under threat or possibly conquest have a resonance which is intensified if public opinion has been prepared for hatred, the rejection of the other, and fear. An example will suffice here. John Dower, in his classical book War Without Mercy (Dower 1986), has clearly demonstrated how, on both the Japanese and the American side, the war had been culturally prepared in advance. The future enemy had to be perceived as barbarous, diabolical, and as a terrifying threat; combatants had had to realize that if the enemy was not killed in battle without mercy, he would kill you without mercy. Here the cultural preparation consisted in dehumanizing the enemy to enable combatants to behave as if they were faced either with human beings who had been reduced to the state of animals, or else demonized. Unfortunately, it is easier to drive a population in this direction rather than the opposite, as Pierre Conessa demonstrates in his book, La fabrication de l'ennemi (Conessa 2012).

It must therefore be admitted that cultural insecurity turns the enemy into an uncivilized creature, culturally diabolical and, in the last resort, closer to a state of nature than of culture; while the protagonist's own 
culture is seen to be an indication of civilization. The cultural insecurity which is experienced in the preparatory phase of a war can be countered by asserting that the enemy's culture is one of evil and destruction, to which the protagonists oppose their own values and their own identity. When it is a question of ending war, or violence, there are problems, but they are not of the same nature.

\section{Exiting internal violence}

In the case of violence within a country, for example when a government organizes a genocide against part of its own population as was the case in the Africa of the Great Lakes where the Tutsis massacred hundreds of thousands of Hutus, or when a military dictatorship was particularly bloodthirsty, as was the case in the 1970s in several countries in Latin America, in the first instance, exiting violence poses the question of how to organize the coexistence of the victims and the executioners within the same country. This is an issue which is often referred to as one of 'peace or justice', and the question raised at the outset is to know how to articulate this twofold demand, if indeed it is possible to do so. The difficulty is that, in the name of peace, the victims have to accept that the perpetrators, if they have retained a degree of capacity for action, may not be punished, or at least, not adequately. Therefore to enable the exercise of a genuine form of justice, the risk is taken of a possible return to violence. This is why the experience of South Africa is so frequently quoted as an example.

Mandela succeeded in implementing a process combining peace and justice, in particular by means of the well-known Truth and Reconciliation Commission (TRC) in 1993, which undoubtedly avoided a bloodbath. It required the immense intelligence and the profound humanism of Mandela, but also of Archbishop Desmond Tutu, for their country to thus put an end to Apartheid. We must insist on one aspect: this was a process of restorative justice, which was offered to South Africans. It was not a pure and simple application of a culture. This process, if we limit ourselves to the work of the Commission, which lasted for some considerable time from 1996 to 1998, demanded a substantial effort on the part of all the various actors who participated therein. They had to work on themselves and, if they wanted to be granted an amnesty, accept to come forward and confess their crimes and demands with no exception. Since then, numerous commissions based on this experience have been formed in approximately 30 countries, in Latin America, Canada, East Timor, and so on, offering what is often referred to as transitional or 'restorative justice' (as opposed to 'retributive justice').

In this perspective, cultural insecurity has been converted into discussions and endeavours to support the country, which has been scarred 
and mortally divided, in its efforts to come to terms with itself. Various forms of cultural innovation can be mobilized to complement the reform movement: theatre, painting, poetry, for example, all serve to help get over the dramatic episodes, by enabling the victims to transform their suffering into mourning.

\section{Ending war}

In the case of wars, exiting violence is increasingly a cause for concern by the powers involved, over and above the protagonists themselves. When an armed conflict exists, the international community, or part at least, may endeavour to impose peace and implement it in the name of humanist values. In these instances, the project is to nurture a tolerant and openminded democratic political culture. Here cultural security is a question of the combination of the democracy and open-mindedness of the two formerly opposed cultures in coming to an understanding. Modern war, for some Western countries at least, is not, as in the past, opposition to an enemy, either as a means of defence or attack, but increasingly tends to be a contribution to peace, or 'peace-building', usually in association with humanitarian organizations, in particular NGOs. Thus, some military operations, in particular when they are backed or organized by the United Nations, are conceived of as being primarily the preparation for a lasting peace which will only come into being if a favourable environment is created or supported with the rule of law, a democratic state, legitimate institutions and political, social and cultural actors capable of discussion and who refuse the return to violence.

But the temporality of violence or of war is not the same as that of culture, analysis, reflection and peace. When the Nazis burnt books or the Taliban shot down the Buddhas in Bamyan in Afghanistan, or when Daesh destroyed the ancient city of Palmyra, we can, at best, attempt to stop the destruction, and this is not a matter of culture, analysis or reflection, but one of weapons. But if in the long run we wish to prevent the existence of such rationales of hatred and destruction, barbarism and refusal of any civilization, then we have to construct culture, and give it permanent value, in particular through education, which is a permanent task over a long period of time.

\section{The mediators}

In numerous experiences, exiting violence depends on the intervention of external actors who are not involved and whose mission is to create the conditions which enable this exit. They are mediators or go-betweens who may in certain circumstances be state-appointed. Thus, Norway played a role in the negotiations in Sri Lanka which ended the guerrilla warfare of 
the Tamil Tigers, and also assisted in the reintegration of the combatants. Norway was active in the Oslo Accords for peace between the Israelis and the Palestinians. Today, Cuba has been hosting the representatives of the government of Columbia and the FARC guerrillas for lengthy negotiations, thus ending a long period of violence. Mediation may also play a role at national level: for example, in France, when Michel Rocard was Prime Minister he set up a mediation scheme which enabled the ending of the violence which had brought bloodshed to New Caledonia, a French territory where the Kanak people, who are the Aborigines and the Caldoches, the French settlers of European descent, were fighting each other. Here, what is at issue is of course humanism, the reference to values enshrined in a culture of peace and of discussion, and not one of violent confrontation and rupture.

If such endeavours are to have any hope of success, various conditions are required. The mediators must be clearly perceived as external to the conflict. They must be accepted by both sides, thus demonstrating that the advocates of violence are not entirely devoid of humanity. The culture of these advocates of violence must be open to the possibility of discussion, the recognition of the enemy as a human being. Statistics show that armed conflicts which end in a negotiation assisted by mediators are much more often settled enduringly than those which end by the victory of one of the sides, and which much more frequently result in a return to violence. The actors must be capable of assuming and internalizing the task of mediation and learn to see each other as partners, as a result of the mediation, capable of discussing and negotiating with each other.

Some of the participants in the Oslo negotiations at the beginning of the 1990s have described in the media what happened. At the outset, the Israelis and Palestinians saw each other as enemies devoid of the slightest humanity. They learnt to recognize each other as human beings, to get to know each other in the relationships which became interpersonal and, from there, to consider together what would lead to peace between their two peoples.

Similarly, Michel Rocard, the French Prime Minister, told me what he did to bring an end to the violent confrontations in New Caledonia. He sent intermediaries who, on the spot, discreetly prepared discussions, and at the final stage he received the leaders of the two groups in Paris and said to them: 'This room is at your disposal - there is food and drinks in the refrigerator. This is the only meeting there will be but it can last as long as you find necessary. It's up to you to find the solution.'

This is indicative perhaps of an approach in terms of democracy and a sense of dialogue, a trend fostered by some cultures, philosophies and values and which ends insecurity, including in its cultural, identity aspects. 
More generally speaking, peace and a strategy for exit from violence cannot take place without the presence of two specific types of actors. These are on one hand, the clercs, or intellectuals, to use the general term popularized by Julien Benda when he denounced the Trahison des Clercs (English translation: The Betrayal of the Intellectuals, by Richard Aldington). They include people within the society in question, possibly heads of organizations or movements, religious leaders, intellectuals, politicians and humanitarian workers who know how to guide their followers towards peace and the refusal of violence. Gandhi is the obvious example to quote here. The other set of actors are the mediators; they are not involved in the action but create the conditions for the actors at war, or involved in violence, to speak to each other, to learn how to get to know each other, and finally to find a negotiated solution which will transform war and violence into peace.

\section{Transforming violence and war into negotiable conflicts and discussion}

This leads to a point which is crucial. Peace and non-violence do not necessarily mean the absence of conflict. Instead, they mean that those who were until then engaged in rationales of belligerency, of rupture or 'war without mercy', in the words of the title of the book by John Dower to which we referred above, accept not to end their differences nor to act as if nothing opposed them to other actors, but to transform their violence, or the war, into a relation which may be conflictual but which enables exchange, discussion and negotiation.

Here, culture, education and values may be useful if they prepare each individual to live in a world in which discussion and negotiable conflict enable different actors to present their ideas and to highlight their interests while continuing to discuss. This applies to international life, in which for example we need to be able to avoid war without the viewpoint of the most powerful necessarily being imposed. This means respect for the rule of law, procedures, agreements and international justice; this must not be a justice of the winners over the vanquished. This also involves the role of the NGOs on one hand, and international organizations such as the United Nations on the other. This applies to life within each individual country. From this point of view, the contribution of culture and values is inseparable from that of democracy, even if the latter frequently appears to be fragile, or even non-operational.

Culture is therefore a necessary condition for democracy and peace: if it is open and humanist, it enables the transition to a less violent internal and international order. But it is also the outcome of this transition. Cultural insecurity is removed or lowered not by war or violence but by the establishment of relations which may be conflictual and discussions which may 
be tense. The best cultural security is the outcome, not of the imposition of cultural norms on the loser, and the denial of their rules and traditions but of the establishment of types of national and international relations in which each culture is recognised, promoted and capable of changing and innovating and not uniquely of being reproduced.

In conclusion, perhaps we could assert that the basis for cultural security is peace, but also discussion, institutionalized conflicts and recognition of the diversity of cultures; these achieve more than exhortations, repressive discourses, walls and borders.

\section{NOTE}

1. As from this point, this chapter incorporates some of the elements from a lecture which I gave at the International House of Japan, in Tokyo, in January 2016.

\section{REFERENCES}

Anderson, B. 1983. Imagined Communities: Reflections on the Origin and Spread of Nationalism. London: Verso.

Appadurai, A. 1996. Modernity at Large: Cultural Dimensions of Globalization. Minneapolis, MN: University of Minnesota Press.

Bauman, Z. 2017. SOCIO, 8 (June), Dossier 'Zygmunt Bauman critique de la modernité'. Paris: Editions de la Maison des Sciences de l'homme.

Benda, J. 2006. The Treason of Intellectuals. New York: Routledge.

Conessa, P. 2012. La fabrication de l'ennemi. Paris: éd. Robert Laffont.

Dower, J.W. 1986. War without Mercy: Race and Power in the Pacific War. New York: Pantheon.

Fribourg Declaration. Cultural Rights. 7 May 2007.

Khosrokhavar, F., Wieviorka, M. 2017. Les juifs, les musulmans et la République. Paris: éd. Robert Laffont.

Kroeber, A.L., Kluckhohn, C. 1952. Culture: A Critical Review of Concepts and Definitions. New York: Vintage Books.

Marshall, T.H. 1963. Citizenship and Social Class. In Class, Citizenship and Social Development. Chicago, IL: Chicago University Press.

Michaels, W.B. 2006. The Trouble with Diversity: How We Learned to Love Identity and Ignore Inequality. New York: Metropolitan.

Tönnies, F. 1887. Gemeinschaft und Gesellschaft, Leipzig: Fues's Verlag (2nd edn 1912, 8th edn, Leipzig: Buske, 1935; reprinted 2005, Darmstadt: Wissenschaftliche Buchgesellschaft).

Weber, M. 2004. The Vocation Lectures. Transl. Rodney Livingstone, ed. D. Owen and T. Strong. Indianapolis, IL: Hackett Books. 